\title{
ICTS, OPENNESS AND CITIZEN PERCEPTIONS OF GOVERNMENT: HOW CIVIC TECHNOLOGIES CAN FACILITATE EXTERNAL CITIZEN EFFICACY
}

\footnotetext{
Rebecca Rumbul

IZVORNI ZNANSTVENI RAD / DOI: 10.20901/ms.7.14.4 / PRIMLJENO: 08.03.2016.
}

\begin{abstract}
This article examines whether civic technologies deliver an effective technique for developing the political efficacy of citizens and altering their perceived accountability of governments. Employing a survey-based methodology, a quantitative analysis was performed on the users of civic technology sites in the USA, UK, Kenya and South Africa. The primary question posed is whether the specific citizen monitoring actions facilitated by these sites cause a related effect in altering the extent to which citizens believe that governments are responsive to citizen-audit. The results indicate an enhancement in citizen efficacy and perceptions of government accountability. Notable differences detected in the user demographics between the countries studied demonstrate a wide spectrum of citizen usage; however, with common confidence displayed by respondents in the efficacy of the ICT. The findings indicate that the publication and citizen-audit of government information through civic technologies in developed and developing countries increases feelings of external efficacy and perceived government accountability.
\end{abstract}

KEY WORDS

DIGITAL DEMOCRACY, POLITICAL EFFICACY, CIVIC TECHNOLOGY, ICT

Author Note

Rebecca Rumbul :: mySociety and Cardiff University, UK :: rebecca@mysociety.org 


\section{INTRODUCTION}

The potential of ICTs to address fundamental democratic and participation issues has been recognised by scholars (Groshek, 2009), in particular with regard to the facilitation of greater 'openness' in governance (Bertot et al., 2012). The logic of employing such digital tools, focused towards the concept of governmental openness is in the link between efficacy and participation (Zimmerman, 1989). The evolution and proliferation of civic technologies, a form of ICT, around the globe has gained pace since the advent of early participatory websites in the early 2000 's, and significant funding is now being allocated to the NGO sector for the development and implementation of such sites in response to improvements in connectivity and access to hardware now occurring in many developing countries. The core purpose of such civic technologies is primarily to empower citizens through enabling some form of civic or political participation and in facilitating the flow of official information, whether that be on a specific policy subject, a specific citizen complaint, or information on parliamentary proceedings.

This study investigated whether civic technologies have an 'empowering' impact upon those individuals that use them, specifically, whether using civic technologies to access information increases, or alters in any way, the personal efficacy and belief of citizens in their ability to hold their governments to account. Research into the mediumlong term impacts of civic technologies upon citizen attitudes is scarce, in part due to the small scale of organisations running these sites, in part due to their youth, and in part due to the transience of the user experience. A very early adopter and developer of civic technologies, mySociety, is based in the UK and operates a range of Open Source civic technology platforms that enable citizens to participate in civic activities, whether that is through a parliamentary monitoring site TheyWorkForYou, through making Freedom of Information requests via WhatDoTheyKnow, or through reporting maintenance issues to local authorities via FixMyStreet. This code is operational in over 40 countries globally. Tobias Escher (2011), examining mySociety website users in the UK, noted that a significant volume of users were first-time users with individual and 'particularised' (Cantijoch et al., 2015) interests. However, it has also been shown that, to a limited degree, such digital platforms demonstrate a correlation with increased community involvement in an offline capacity (Cantijoch et al., 2015). Marta Cantijoch et al.'s (2015) research demonstrates that, whilst individual interests drive initial online participation, the very act of online participation may alter the subsequent attitudes or actions of citizens.

What is not currently evidenced is what attitudes towards the use of these civic technologies themselves, and towards government, are developed by citizens in the process of their action. Civic technologies enable participation, but to what end? Civic technologists themselves describe their aims variously as enabling transparency to facilitate the accountability of, or the exertion of power over, government institutions (Rumbul, 2016).

This study examined the attitudes of citizens using civic technologies in the UK, South Africa, Kenya and the US. Quantitative data was collected via online surveys, as well as 
via online analytics programmes to address the question of whether the use of civic technologies increases personal external efficacy, alters the confidence citizens hold in their respective governments, and whether specifically, that can be attributed to their ability to participate via civic technologies.

This research is both novel and significant in its approach. Civic technologies have been subject to a much lower volume of scrutiny in their role in citizen participation than social media platforms or dedicated petition sites, however, these websites have been recognised by governments and commentators as a potentially effective route to diversifying and broadening participation (Bertot et al., 2010; Olphert and Damodaran, 2007). This study sheds light on whether those assertions may be correct, and provides substantive evidence of attitudinal change in citizen's engagement with civic activities. This study also illuminates previously unexamined public attitudes towards civic technologies, delineating the confidence citizens have in the civic technologies they are using, and the confidence citizens have or develop in their governments through the use of civic technologies.

\section{THE ROLE OF EFFICACY AND THE PROBLEM OF PARTICIPATION}

Significant volumes of individuals now use the internet as one of their primary sources of news and political information (Graham and Metaxas, 2003; Johnson and Kaye, 2010; Kenski and Stroud, 2006), and many use it as their primary medium of personal administration, whether that takes the form of using online banking services, purchasing consumer goods, or arranging a family holiday. Internet users therefore have a reasonable level of efficacy in navigating their online environment. Citizens in many countries do not, however, exhibit high levels of personal efficacy in their civic or political spheres (Bromley et al., 2001; Forrest and Weseley, 2007; Francis and Busch, 1975). Political efficacy has been described by several authors as possessing two distinct constructs, distinguishing between 'internal' and 'external' dimensions of the concept of efficacy (Balch, 1974; Converse, 1972; Kenski and Stroud, 2006; Niemi et al., 1991). Whilst internal efficacy concerns the understanding of one's own ability to understand and participate, external efficacy refers to the extent to which citizens believe governments and authoritative institutions will be responsive to citizen demands or participation (Finkel, 1985; Niemi et al., 1991). The literature suggests that citizen beliefs concerning government responsiveness, in the absence of personal experience, directly affects the extent to which citizens will choose to participate (Abramson and Aldrich, 1982; Finkel, 1985; Sjoberg et al., 2015).

The digital availability of political and governance-related information does not necessarily mean that individuals will alter their approaches to engaging with civic activity (Kenski and Stroud, 2006), however scholars have pointed to internet connectivity as a tool for enhanced democracy and participation (Anderson, 2003). The study of political efficacy has historically centred around traditional forms of political participation (Craig and Maggiotto, 1982; Finkel, 1985), and in recent years, the equivalent actions conducted through digital means (Bennett et al., 2009; Dimitrova et al., 2011). Such activities include 
verbal or financial support of political campaigns, dissemination of partisan policy messages, and participation in meetings and elections. Civic participation, however, encompasses a broader field of concern than that specific to party political ideals, providing space for individual participation and engagement in civic issues external to partisan boundaries. Individual citizens are able to raise issues, investigate them, and communicate them through digital means in a quicker and potentially more impactful fashion than in the pre-digital age. Whilst this form of political participation largely concerns organised issue-specific lobbying and campaigning, the digital ability to conduct such activities also enables citizens to pursue very individualised, participatory agendas, often referred to as 'particularised contacting' (Cantijoch et al., 2015; Teorell et al., 2007). Some authors have considered this as a diminished form of political participation, ranking it amongst routine administrative activities (Parry et al., 1992; Verba et al., 1995) or failing to distinguish these activities from larger-scale contact concerning macro-political concerns (Teorell et al., 2007), however these activities, conducted through civic technologies, have been shown to have specific impacts upon citizen behaviour in regard to both community-based civic activity (Cantijoch et al., 2015) and in engaging with government concerning microlevel individualised issues (Sjoberg et al., 2015). It is possible to posit, therefore, that this particularised form of civic engagement may impact the levels of confidence that citizens hold in government and its ability to account for its actions.

The concepts of confidence and trust in government have been examined by a number of scholars, many of whom have identified a trend in decreasing levels of trust and confidence in government (Levi and Stoker, 2000; Nye et al., 1997). In consideration of such findings, several authors have emphasised the role that accountability and transparency hold in potentially reducing levels of mistrust (Norris et al., 2001; Thomas and Streib, 2003; Tolbert and Mossberger, 2006). Scholars studying accountability and transparency have identified the role that the publication of official information plays in achieving what is perceived to be a more accountable government (Ball, 2009; Pasquier and Villeneuve, 2011). The citizens ability to review information about or produced by governments and politicians is one aspect of increasing personal external efficacy (Bundy, 2004; Kenski and Stroud, 2006; Usluel, 2007). The ability to see official information and use it to monitor or query governments and politicians is therefore important in engaging citizens in good governance and in impacting their own efficacy.

In considering the emergence of digital methods for accessing information, authors (Bertot et al., 2010; Norris et al., 2001) identified the potential of e-government in particular in facilitating an increase in transparency and accountability in government administration and service delivery, potentially resulting in increased efficiencies and better communication that would bolster citizen confidence in government overall. However, studies of the weaknesses or risks associated with e-government have also identified links between citizen trust in government and the propensity to use e-government systems (Bélanger and Carter, 2008), and the tendency of e-government initiatives to become bureaucratically rationalised rather than customer-focused (Colesca, 2009; Moon and Welch, 2005). E-government itself is, therefore, not a perfect tool for citizen engagement or increasing citizen efficacy, even though it is a tool for citizen audit (Margetts, 2011). 
Civic technologies provide a potential solution to the concerns that citizens may hold in government-run digital services. Unlike e-government, civic technologies operate at the intersection of e-government and civil society. In the majority of cases, run by NGOs, civic technologies seek to expand the ability of the citizen to engage with governance mechanisms in a digital way rational to the user, whether in a form of particularised contacting in which the citizen interacts with an official individual, or in a citizen audit role in which the citizen is able to acquire and review official information on the activities of governments and politicians. In a controlled experiment, John Tedesco (2007) demonstrated the potential for effective interactive digital engagement to increase political information efficacy in young people. This paper seeks to build on Tedesco's findings by drawing and examining data from a diverse, real-world user base.

Building on the literature concerning ICTs, external efficacy and openness, this research seeks to uncover possible links between the use of civic technologies and efficacy. This study examines the external efficacy of participants through their 'particularised' use of civic technologies, and asks

$>$ Who is using civic technology platforms?

>How are civic technology platforms altering levels of external citizen efficacy and confidence in governmental institutions?

The study examines any alteration in such levels of efficacy, analysing this alongside perceptions of government behaviour in relation to the existence of civic technologies. This study seeks to identify those individuals already using civic technologies, and therefore expects that the demographic spread of users may be uneven as a result of issues discussed in the literature such as the 'digital divide' (Norris, 2001) that exists within each country.

\section{DATA AND METHODS}

This study examined five civic technology sites operating in the UK, USA, Kenya and South Africa. These countries were selected for three common factors:

>The presence of a well-used (above 5,000 individual users per month) and non-partisan civic technology platform;

$>$ The broad ability amongst the general population to hold sufficient connectivity in a personal capacity in order to access online services regularly;

$>$ A multi-party political system holding free and fair elections with a distinct executive and legislative form of government.

These countries were also selected for their differences. Technologies are used in different ways in different territories, and there was the potential for this study to compare attitudes and efficacy. The UK and the US represent highly developed countries with historic political and governmental systems, high levels of connectivity, and well 
established methods of political engagement. Kenya and South Africa however, are developing nations. These countries have politically engaged populations, however their systems of politics and engagement are not as well established as those in the UK and the US, widespread connectivity is a relatively new phenomenon facilitated by recent advances in mobile technology, and access to political and governmental proceedings remains difficult. The differences in historic and political experience in these countries could potentially manifest in contrasting usage and attitudinal patterns within this study, and such data could be valuable not only in further study, but in the practical development of future civic technologies.

The study draws on 4,233 survey responses from civic technology users, and focuses on examining the basic demographic information and public attitudes data. The participating sites were FixMyStreet (UK), TheyWorkForYou (UK), GovTrack (US), Mzalendo (Kenya), and People's Assembly (South Africa). Each of these civic technology platforms provides users with either the opportunity for particularised contacting (FixMyStreet) or citizen parliamentary audit (TheyWorkForYou, GovTrack, Mzalendo and People's Assembly). The users of each site were asked if they would be willing to complete a survey for research purposes. This invitation would either be presented following a transaction, such as would occur following the submission of a report on FixMyStreet, or a pop up invitation would be presented to a user following a minimum time period on one site (for sites that were non-transactional, such as GovTrack). High-traffic sites, such as those operating in the UK and US, only invited a sample of visitors to take the survey. In the UK this was $50 \%$ of site users (or every other user), and in the US this was $25 \%$ (or every 4 users). Lower traffic sites such as Mzalendo in Kenya and People's Assembly in South Africa invited $100 \%$ of users to participate in order to ensure a sufficient sample. All surveys were conducted exclusively online, and consisted of between 17-21 questions (certain additional questions were added at the request of the participating platforms). No information on identification was requested. The first half of the survey requested personal demographic information such as age, level of educational attainment, economic activity, and employment sector. The second half of the survey included questions concerning the attitudes of individual users towards the civic technology they were using and their government and institutions. These questions sought to examine the perception of users concerning the benefits of the tools they were making use of above any other methods of providing or acquiring information from the government, their confidence in governance structures, and their perceptions of the effect of civic technologies upon government behaviour. Questions did not directly ask about levels of confidence or trust, rather, they focused on the individual's assessment of government behaviour, perceived ability to hold government to account, and the expectation of government behaving in a different manner in the event that the information and functionality of civic technology sites did not exist. The data was collected between February 2015 and October 2015. 


\section{FINDINGS}

\section{Efficacy and confidence in governmental institutions}

The data, somewhat unsurprisingly, shows that users of these specific civic technologies hold a pre-existing interest in politics, with over $70 \%$ of users confirming some daily consumption of political news in the UK and the US, and $58 \%$ and $66 \%$ in Kenya and South Africa respectively. This is perhaps unsurprising given the political and government content of such civic platforms, and reinforces previous research findings that show efficacy in an offline context translates into efficacy in an online context (Kenski and Stroud, 2006).

$\% \quad \%$ of respondents consuming news at least once per day

100

80

72

77

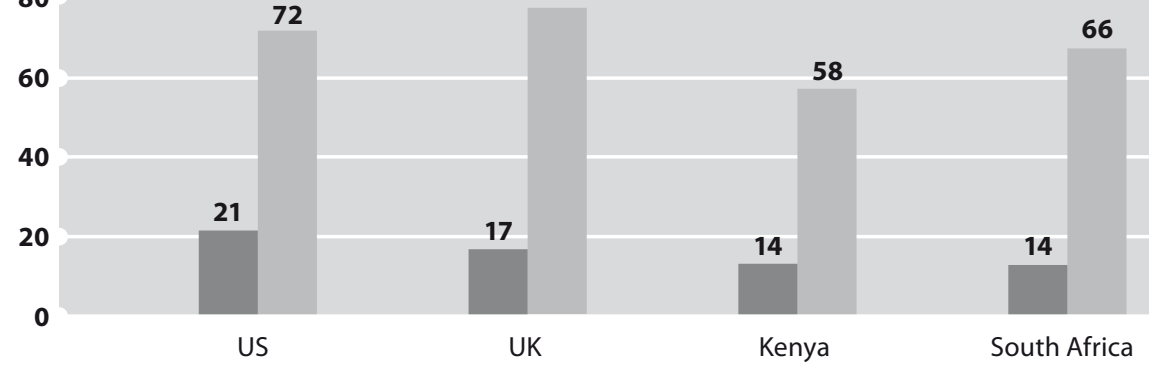

A Figure 1.

Political news consumption

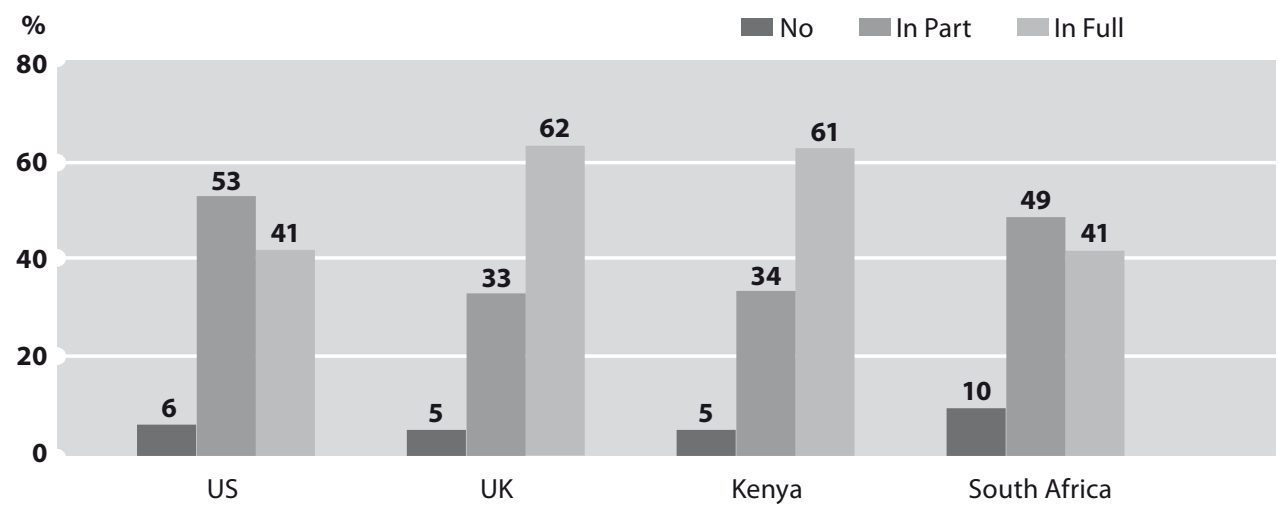

A Figure 2.

Responses to the question 'Do you believe that being able to see this kind of information enables you to hold government/politicians to account?' 
The number of users believing that such civic platforms enable them to hold governments and politicians to account was extremely high across all platforms surveyed. Over $94 \%$ of individuals in the UK felt that being able to see the information displayed through the civic technology site TheyWorkForYou enabled them, at least in part, to hold the British government to account. In the US, this was 95\%, in Kenya 94\%, and in South Africa 91\%.

These figures are noteworthy, and strongly suggest a link between access to official information and external efficacy. Such beliefs indicate that individuals have confidence in their online actions serving a higher purpose than mere curiosity, in this case, viewing political and governmental information online through a civic technology platform. The data also alluded to a certain level of mistrust felt by many citizens in government behaviour. In Kenya, $83 \%$ of users believed that their ability to scrutinise government information via the Mzalendo platform directly affected how politicians behaved, and over $92 \%$ believed that those politicians would behave differently if the information displayed on Mzalendo was not available digitally in the public domain. These figures were mirrored in all five cases, demonstrating similar levels of belief in both developed countries (the UK and the US) and developing nations (Kenya and South Africa). The cross-tabulation of the responses shows a statistically significant difference in the beliefs of respondents with respect to their access to information being an influence upon government behaviour $(p<0.0001)$. These beliefs indicate a level of efficacy directly related to the user's ability to review political or governmental information online, and that action, in some way, affecting the behaviour of government.

Significantly, a high volume of users across the four parliamentary monitoring platforms were unaware of other methods of accessing the information contained on those sites. Fully $48 \%$ in Kenya, 55\% in South Africa, and $68 \%$ in the UK were unaware of other methods of accessing parliamentary information. Similarly, 55\% of users of 'particularised' contacting civic technology site FixMyStreet in the UK were unaware of any other method of reporting issues to their local authority. This is not surprising, as many official government and parliamentary websites are difficult to navigate, search or interact with, and many official organisations do not upload the volume or quality of information contained on the civic technology platforms. Whilst across the four countries studied access to official information is generally granted, it can also be a lengthy or cumbersome process to acquire, and the process itself is not widely understood. There is therefore the possibility that, prior to information being displayed via civic technologies, citizens were unaware that they were entitled to see such information. The findings of this study indicate that such information disclosure and public display may be valuable in raising personal external political efficacy.

\section{Demographics}

The data collected demonstrates a wide demographic spectrum of civic technology usage. Individuals responded within each of the age brackets surveyed, demonstrating that such digital tools are potentially useful for citizens of any adult age group. In the US and the UK, the majority of users were found to be from older demographic groups. 
FixMyStreet in the UK registered $48 \%$ of users over the age of 55 , and another $22.6 \%$ of users who identified as being in the 46-55 category. This means that the under 45's comprise under $30 \%$ of the user base. The US produced similar age-related results. The over 55 age group comprises $55 \%$ of GovTrack users, and adds another $19 \%$ into the 46-55 category, showing that $74 \%$ of the sites users are over 45 . These results contrast significantly with the results from Kenya and South Africa, where only $14 \%$ and $34 \%$ of users respectively are over the age of 45 .

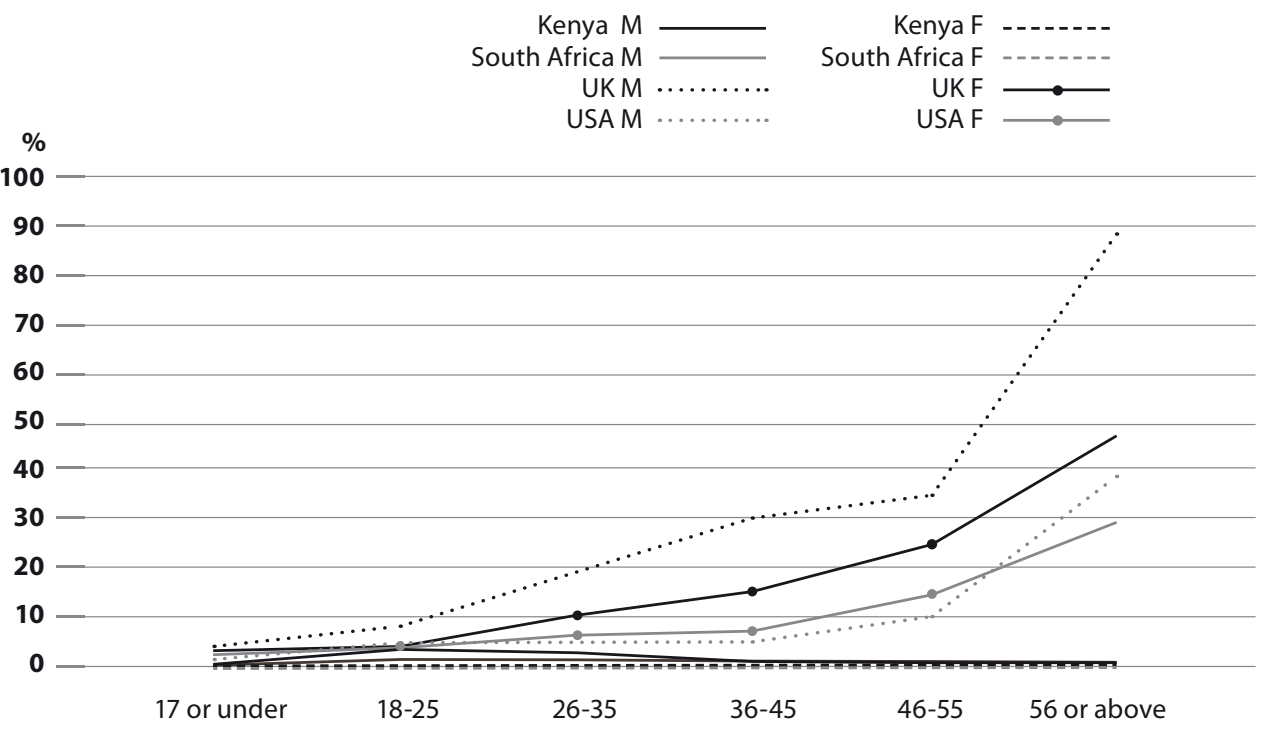

\section{$\Delta$ Figure 3. \\ User demographics: Age and gender by country}

Interestingly, the trend towards higher usage amongst older male and female users in the UK and the US is not seen among users in South Africa and Kenya, where there is a declining trend in usage towards the older age brackets. Overall, the average age of users across the entire sample was calculated at 53 years of age; however, the country-specific calculations paint a very different picture. Average user ages in Kenya are calculated at just 32, and in South Africa, 39 years.

The difference between the age and gender profile across the four participating countries is also noteworthy. The findings clearly show that individuals identifying as male comprise a disproportionate part of the civic technology user base. The gender balance of the civic technology user bases examined was much less evident in the US than in the UK, Kenya and South Africa. The data collected from South Africa showed a $68 \%$ male user base, and in Kenya, a $72 \%$ male user base. Whereas $64 \%$ of users of FixMyStreet in the UK 
identified as male, the US site GovTrack had a more balanced $52 \%$ of users identifying as male. This male user bias is reinforced by previous studies by Tobias Esher (2011) and Gibson, Cantijoch and Galandini (2014) which examined a number of mySociety's UK websites. These studies detected a male user bias of $66 \%$ and $64 \%$ respectively. It is unclear what causes this imbalance in the gender of citizen users of civic technology, however the imbalance is concerning in light of any potential for civic technologies to demonstrate contributions to increasing efficacy. Differences in the gender and age identification may emerge as a result of a self-selection bias, which is a weakness in this method of surveying, however a comparison with previous research and with Google Analytics tools did not uncover differences in usage patterns.

In all four countries sampled women remain slightly less engaged in politics than men. Tools, such as civic technologies, have previously been theorised as helping reduce barriers to political participation. If these ICTs are not achieving this aim, further research into the gender imbalance of civic technology users would be valuable in understanding how such tools could be harnessed for the public good. Citizens using civic technologies in all the studied areas tended to be well-educated, with between $40-60 \%$ of citizens holding at least degree-level qualifications, however fewer were economically active, with less than $50 \%$ of users across all sites in full-time employment or education. In the UK and the US, economically inactive users tended to identify as retired, whereas in Kenya and South Africa, economically inactive users identified as unemployed and looking for work.

These findings, whilst for the most part being descriptive, nonetheless provide a brief overview of both the feelings of external efficacy, and the user profiles of politicallyrelated civic technologies in Kenya, South Africa, the US and the UK. Whilst the data makes a distinction between user profiles in the UK and the US as users are mostly older, male and well-educated, and in Kenya and South Africa as users are mostly young, male and with a standard level of education, there are key similarities in the response rates of questions relating to efficacy. Such commonalities in these efficacy related questions suggest that civic technologies have some positive and discernible effect on efficacy.

\section{CONCLUSION}

This paper makes a novel contribution to the study of online participation through civic technology and e-democracy platforms. Substantively, it has provided a new insight into the question of which citizens currently use civic technologies, and how these platforms shape their attitudes and opinions concerning their respective governance structures. The comparative cases used demonstrate both the differences and the similarities in usage and attitudes in both developed (the UK and the US) and developing (South Arica and Kenya) countries. Through combining questions concerning attitudes to government, and the perceived effects of civic technologies upon government behaviour, the research has shown a clear indication of civic technologies facilitating political efficacy amongst civic technology users. 
The overarching question posed by this research concerned individual external efficacy in civic engagement. In particular, the research examined whether citizens using civic technologies developed increased personal efficacy as a result of using these digital tools. The findings suggest that the use of civic technologies could contribute to increasing the external political efficacy of individual citizens. The majority of citizens using civic technologies in a citizen audit or particularised contacting role confirmed that the use of such platforms enabled them in their own way, and at least in part, to hold their respective governments to account. This self-reported level of efficacy does not confirm that these individuals would actually use the information or experience acquired via civic technologies for further political or civic activities. However, taking into consideration the linked findings concerning the majority of individuals that knew of no other way to engage with government, the data does indicate that the very ability to engage with governance mechanisms rationally, through digital means, is sufficient in itself to increase individual external efficacy.

The importance of this finding is emphasised by the low levels of trust exhibited by participants. The second question asked by this paper concerned the individual citizen perception of government actions and behaviours, and examined whether citizens felt that the availability of official parliamentary and administrative information online in any way affected the conduct of government officials. The majority of participants believed that their ability to engage with their respective governments through civic technologies affected how those governments behaved, and believed that those governments would behave differently if these methods of engagement were not available. This is an important finding in relation to the question of citizen efficacy. External efficacy concerns the extent to which citizens believe that the government apparatus is responsive to their demands and their actions. Through the use of civic technologies in this study and as a result of the existence of these technologies, citizens felt that government behaviour would in some way be different from government conduct in the absence of those platforms.

Lastly, this study examined the demographic and attitudinal spectrum of civic technology users comparatively, across both developed and developing nations. The comparative examination of such data is of practical importance given the increasing use of ICTs and civic technologies in improving citizen engagement in developing countries. It is quite possible that civic technologies and their users differ greatly between nations; however this has not been demonstrated in the literature. The data gathered for this research demonstrated the significant variability in demographic trends between the countries included in the research, and should serve as a caution to researchers examining tech such as this in generalising findings across countries. If the data taken from this study is grouped into one single data set, a moderately rounded picture of demographic spread is produced. This however, hides the significant differences in demographic spread when the data is broken down by country. Analysed at country level, the data evidences very deep demographic differences. The most stark comparative results concerned the age profile of ICT users, with older individuals of 45 and over dominating civic technology usage in the UK and the US, whereas individuals under 45 dominated usage in Kenya and South Africa. Female users were also under-represented in the study 
in all countries with the exception of the US. These demographic findings demonstrate that the implementation of civic technologies cannot be standardised across borders and produce the same results. Whilst civic technologies have been shown in this study and by previous authors to have positive citizen outcomes (Cantijoch et al., 2015; Sjoberg et al., 2015), in practice their development, implementation, and usage will be nuanced and will need to accommodate local and national cultural differences in digital engagement, access and skills. The digital divide that exists in developed countries such as the UK and the US affects low income, lower educated, and minority ethnic groups of all ages (Liff et al., 2004; Sarkar et al., 2007), whereas in Kenya and South Africa, the divide affects low income, older, black, female, and more rurally located groups (Buys et al., 2009; Fuchs and Horak, 2008). These national differences in the digital divide will inevitably affect the extent to which civic technologies can be seen to empower those that are not already reasonably comfortable interacting with political information in an online format. Given the demographic differences in civic technology usage examined in this research, the ability of civic technologies to universally affect citizens' external efficacy will likely be limited.

This study operated as a pilot project in an operational environment of which very little was known or studied. It has a number of flaws, including the differences in sample size between participating nations, which required a comparative individual nation analysis rather than analysis of the complete data set. Many of the questions also tended towards descriptive measures and required self-reporting of subjective beliefs and feelings. These factors mean that no absolute certainty can be attributed to the findings; however, the findings were considered sufficiently robust and interesting to indicate that this is an area rich for future exploration. The enduring presence of a digital divide within each of the nations studied also limits the scope of the findings to those individuals with existing digital skills. Further rigorous research into this emerging area of digital activity is required to penetrate the indications of increased efficacy discussed in this article, and the results should also act as a practical and cautionary tool for practitioners designing and implementing civic technologies across borders.

This study has presented a novel approach to examining external efficacy and government transparency through ICTs; however, further study of this growing sphere of activity is needed to fully uncover the true potential of civic technologies in improving citizen participation. Such digital solutions are increasingly discussed by governments and NGOs as possible tools for citizen engagement; however until more is known about the people that use these platforms, the way they engage, and how they feel about their engagement, the overall impact of such technologies will remain limited.

\section{References}

>Abramson, Paul R. and Aldrich, John H. (1982) The Decline of Electoral Participation in America. American Political Science Review 76: 502-521.

>Anderson, David M. (2003) Cautious Optimism about Online Politics and Citizenship, pp. 19-34 in Anderson, David and Cornfield, Michael M. (eds) The Civic Web: Online Politics and Democratic Values. Oxford, England: Rowman \& Littlefield. 
>Balch, George I. (1974) Multiple Indicators in Survey Research: The Concept "Sense of Political Efficacy". Political Methodology 1: 1-43.

>Ball, Carolyn (2009) What is Transparency?. Public Integrity 11 (4): 293-308. DOI: 10.2753/

PIN1099-9922110400.

>Bélanger, France and Carter, Lemuria (2008) Trust and Risk in E-government Adoption. The Journal of Strategic Information Systems 17 (2): 165-176.

>Bennett, Lance W., Wells, Chris and Rank, Allison (2009) Young Citizens and Civic Learning:

Two Paradigms of Citizenship in the Digital Age. Citizenship Studies 13 (2): 105-120. DOI:

10.1080/13621020902731116.

>Bertot, John Carlo, Jaeger, Paul T. and Grimes, Justin M. (2012) Promoting Transparency and Accountability Through ICTs, Social Media, and Collaborative E-government. Transforming Government: People, Process and Policy 6 (1): 78-91.

>Bertot, John Carlo, Jaeger, Paul T. and Grimes, Justin M. (2010) Using ICTs to Create a Culture of Transparency: E-government and Social Media as Openness and Aanti-corruption Tools for Societies. Government Information Quarterly 27 (3): 264-271. DOI: 10.1016/J.GIQ.2010.03.001. >Bromley, Catherine, Curtice, John and Seyd, Ben (2001) Political Engagement, Trust and Constitutional Reform, pp. 199-226 in Park, Alison, Curtice, John, Thomson, Katarina, and Bromley, Catherine (eds) British Social Attitudes: The 18th BSA Report-Public Policy, Social Ties. London: Sage. $>$ Bundy, Alan (2004) Australian and New Zealand Information Literacy Framework. Principles, standards and practice, 2nd ed. Adelaide: Australian and New Zealand Institute for Information Literacy.

>Buys, Piet, Dasgupta, Susmita, Thomas, Timothy S. and Wheeler, David (2009) Determinants of a Digital Divide in Sub-Saharan Africa: A Spatial Econometric Analysis of Cell Phone Coverage. World Development 37 (9): 1494-1505. DOI: 10.1016/j.worlddev.2009.01.011.

>Cantijoch, Marta, Galandini, Silvia and Gibson, Rachel (2015) 'It's Not About Me, It's About My Community': A Mixed-method Study of Civic Websites and Community Efficacy. New Media \& Society 18 (9): 1896-1915.

>Cantijoch, Marta, Galandini, Silvia and Gibson, Rachel (2014) Civic Websites and Community Engagement: A Mixed Methods Study of Citizen Empowerment Initiatives. In APSA 2014 Annual Meeting Paper. Washington, DC: APSA.

>Colesca, Sofia Elena (2009) Increasing E-trust: A Solution to Minimize Risk in E-government Adoption. Journal of applied quantitative methods 4 (1): 31-44.

>Converse, Phillip E. (1972) Change in the American Electorate, pp. 263-337 in Campbell, Angus and Converse, Phillip E. (eds) The Human Meaning of Social Change. New York: Russell Sage Foundation. $>$ Craig, Stephen C. and Maggiotto, Michael A. (1982) Measuring Political Efficacy. Political Methodology 9 (1): 85-109.

>Dimitrova, Daniela V., Shehata, Adam, Strömbäck, Jesper and Nord, Lars W. (2011) The Effects of Digital Media on Political Knowledge and Participation in Election Campaigns: Evidence from Panel Data. Communication Research 41 (1): 95-118. DOI: 10.1177/0093650211426004.

>Escher, Tobias (2011) TheyWorkForYou.com. Analysis of users and usage for UK Citizens Online Democracy. UK Citizens Online Democracy. https://www.mysociety.org/files/2011/06/ TheyWorkForYou_research_report-2011-Tobias-Escher1.pdf (26.02.2016).

>Finkel, Steven E. (1985) Reciprocal Effects of Participation and Political Efficacy: A Panel Analysis. American Journal of Political Science 29 (4): 891-913. DOI: 10.2307/2111186.

>Forrest, Andrew L. and Weseley, Allyson J. (2007) To Vote or Not to Vote? An Exploration of the Factors Contributing to the Political Efficacy and Intent to Vote of High School Sudents. Journal of Social Studies Research 31 (1): 3-11.

>Francis, Joe D. and Busch, Lawrence (1975) What We Now Know about "I Don't Knows". The Public Opinion Quarterly 39 (2): 207-218.

>Fuchs, Christian and Horak, Eva (2008) Africa and the Digital Divide. Telematics and Informatics 25 (2): 99-116. DOI: 10.1016/j.tele.2006.06.004. 
>Graham, Leah and Metaxas, Panaglotis Takis (2003) Of Course it's True; I Saw It on the Internet!: Critical Thinking in the Internet Era. Communications of the ACM 46 (5): 70-75.

$>$ Groshek, Jacob (2009) The Democratic Effects of the Internet, 1994 - 2003 A Cross-

National Inquiry of 152 Countries. International Communication Gazette 71 (3): 115-136. DOI: $10.1177 / 1748048508100909$.

>Johnson, Thomas and Kaye, Barbara (2010) Choosing is believing? How Web Gratifications and Reliance Affect Internet Credibility among Politically Interested Users. Atlantic Journal of Communication 18 (1): 1-21. DOI: 10.1080/15456870903340431.

>Kenski, Kate and Stroud, Natalie J. (2006) Connections between Internet Use and Political Efficacy, Knowledge, and Participation. Journal of Broadcasting \& Electronic Media 50 (2): 173-192. DOI: 10.1207/s15506878jobem5002_1.

>Levi, Margaret and Stoker, Laura (2000) Political Trust and Trustworthiness. Annual Review of Political Science 3: 475-507.

>Liff, Sonia, Shepherd, Adrian, Wajcman, Judy, Rice, Ronald and Hargittai, Eszter (2004) An Evolving Gender Digital Divide?. OII Internet Issue Brief (2). http://ssrn.com/abstract=1308492 (25.10.2016). DOI: 10.2139/ssrn.1308492.

>Margetts, Helen (2011) The Internet and Transparency. The Political Quarterly 82 (4): 518-521. DOI: 10.1111/j.1467-923X.2011.02253.x.

$>$ Moon, Jae M. and Welch, Eric W. (2005) Same Bed, Different Dreams? A Comparative Analysis of Citizen and Bureaucrat Perspectives on E-government. Review of Public Personnel Administration 25 (3): 243-264. DOI: $10.1177 / 0734371 X 05275508$.

$>$ Niemi, Richard G., Craig, Stephen C. and Mattei, Franco (1991) Measuring Internal Political Efficacy in the 1988 National Election Study. American Political Science Review 85: 1407-1413. DOI: $10.2307 / 1963953$.

$>$ Norris, Donald F., Fletcher, Patricia D. and Holden, Stephen (2001) Is Your Local Government Plugged In? Highlights of the 2000 Electronic Government Survey. International City/County Management Association and Public Technology, Inc. www.umbc.edu/mipar/final_draft/PDFs/e-gov.icma. final-4-25-01.pdf (15.01.2016).

>Norris, Pippa (2001) Digital Divide: Civic Engagement, Information Poverty, and the Internet Worldwide. Cambridge: Cambridge University Press. DOI: 10.1017/CBO9781139164887.

$>$ Nye, Joseph S. Jr., Zelikow, Phillip D. and King, David C. (1997) Why People Don't Trust Government. Cambridge, MA: Harvard University Press.

$>$ Olphert, Wendy and Damodaran, Leela (2007) Citizen Participation and Engagement in the Design of E-government Services: The Missing Link in Effective ICT Design and Delivery. Journal of the Association for Information Systems 8 (9): 491-507.

$>$ Parry, Geraint, Moyser, George and Day, Neil (1992) Political Participation and Democracy in Britain. Cambridge, NY: Cambridge University Press. DOI: 10.1017/CBO978511558726.

>Pasquier, Martial and Villeneuve, Jean-Patrick (2007) Organizational Barriers to Transparency

a Typology and Analysis of Organizational Behaviour Tending to Prevent or Restrict

Access to Information. International Review of Administrative Sciences 73 (1): 147-162. DOI: $10.1177 / 0020852307075701$.

$>$ Rumbul, Rebecca (2016) Who Benefits From Civic Technology?. Oxford: mySociety. https://www. mysociety.org/files/2015/10/demographics-report.pdf (25.10.2016).

>Sarkar, Urmimala, Karter, Andrew J., Liu, Jennifer Y., Adler, Nancy E., Nguyen, Robert, López, Andrea and Schillinger, Dean (2011) Social Disparities in Internet Patient Portal Use in Diabetes: Evidence That the Digital Divide Extends beyond Access. Journal of the American Medical Informatics Association 18 (3): 318-321.

>Sjoberg, Frederik M., Mellon, John and Peixoto, Tiago (2015) The Effect of Government Responsiveness on Future Political Participation. https://papers.ssrn.com/sol3/papers.cfm?abstract_ $\mathrm{id}=2570898$ (15.01.2016). DOI: 10.2139/ssrn.2570898. 
IZVORNI ZNANSTVENI RAD / DOI: 10.20901/ms.7.14.4 / PRIMLJENO: 08.03.2016.

$>$ Tedesco, John C. (2007) Examining Internet Interactivity Effects on Young Adult Political Information Efficacy. American Behavioral Scientist 50 (9): 1183-1194. DOI: $10.1177 / 0002764207300041$.

>Teorell, J., Torcal, M. and Montero, J. R. (2007) Political Participation: Mapping the Terrain, pp. 334-357 in van Deth, Jan W., Montero, Ramon and Westholm, Anders (eds) Citizenship and Involvement in European Democracies: A Comparative Analysis. London: Routledge.

>Thomas, John Clayton and Streib, Gregory (2003) The New Face of Government: Citizen-initiated Contacts in the Era of E-government. Journal of Public Administration Research and Theory 13 (1):

83-102. DOI: 10.1093/jpart/mug010.

$>$ Tolbert, Caroline J. and Mossberger, Karen (2006) The Effects of E-government on Trust and Confidence in Government. Public Administration Review 66 (3): 354-369. DOI:

10.1111/j.1540-6210.2006.00594.x.

>Usluel, Yasemin K. (2007) Can ICT Usage Make a Difference on Student Teachers' Information Literacy Self-efficacy. Library \& Information Science Research 29 (1): 92-102.

$>$ Verba, Sidney, Schlozman, Kay L. and Brady, Henry E. (1995) Voice and Equality: Civic Voluntarism in American Politics. Cambridge: Harvard University Press.

>Zimmerman, Marc A. (1989) The Relationship between Political Efficacy and Citizen Participation: Construct Validation Studies. Journal of Personality Assessment 53 (3): 554-566. DOI: 10.1207/

s15327752jpa5303_12. 


\section{INFORMACIJSKE I KOMUNIKACIJSKE TEHNOLOGIJE, OTVORENOST I GRAĐANSKA PERCEPCIJA VLADE: KAKO „GRAĐANSKE TEHNOLOGIJE“" MOGU OMOGUĆITI VANJSKU UČINKOVITOST GRADANA}

\section{Rebecca Rumbul}

SAŽETAK U ovom se radu istražuje mogu li "građanske tehnologije" (tehnologije koje potiču aktivno građanstvo) na efikasan način razvijati političku učinkovitost građana i mijenjati njihovu percepciju odgovornosti vlade. Anketirani su korisnici "građanskih tehnologija" na mrežnim stranicama iz SAD-a, UK-a, Kenije i Južnoafričke Republike. Temeljno je pitanje bilo jesu li određene građanske akcije nadzora, koje je moguće provesti putem tih mrežnih stranica, utjecale na promjenu mišljenja građana o tome reagiraju li vlade na građanski nadzor. Rezultati ukazuju na poboljšanu građansku učinkovitost, kao i na povećanu percepciju odgovornosti vlade. Između korisnika "građanskih tehnologija" koji dolaze iz proučavanih zemalja uočene su značajne demografske razlike koje su povezane sa širokim spektrom načina na koje građani koriste informacijske i komunikacijske tehnologije (IKT). Ipak, svima im je zajedničko povjerenje u učinkovitost tih tehnologija. Rezultati upućuju na to da objavljivanje i građanski nadzor vladinih informacija putem "građanskih tehnologija" povećavaju osjećaj vanjske učinkovitosti $i$ percepciju odgovornosti vlade, kako u razvijenim zemljama tako i u zemljama u razvoju.

KLJUČNE RIJEČI

DIGITALNA DEMOKRACIJA, POLITIČKA UČINKOVITOST, , GRAĐANSKE TEHNOLOGIJE (TEHNOLOGIJE KOJE POTIČU AKTIVNO GRAĐANSTVO), IKT

Bilješka o autorici

Rebecca Rumbul :: mySociety i Sveučilište Cardiff, Ujedinjeno Kraljevstvo :: rebecca@mysociety.org 